\title{
Using a Phonetics Transcription to Improve Word Stress in Pronunciation for Thai Learners
}

\author{
Sukanya Chootharat ${ }^{1}$ and Anchalee Veerachaisantikul ${ }^{2}$ \\ Department of English, Faculty of Sciences and Liberal Arts, \\ Rajamangala University of Technology Isan, Nakhon Rachasima, Thailand
}

\begin{abstract}
The purposes of this study aimed to explore and improve learners' pronunciation focusing on word stress through a phonetics transcription. The study attempted to determine: a) whether a phonetics transcription can enhance the ability of university-level learners' in pronouncing word stress and; $b$ ) what are the attitudes of learners towards a phonetics transcription. To achieve these purposes, a purposive sample of first year bachelor's degree learners majoring in English for International Communication at Rajamanagala University of Technology Isan, Nakhon Ratchasima were selected as the participants. The instruments of this study comprised pre and post pronunciation tests, and a questionnaire. The quantitative data were analyzed and interpreted with the use of frequencies, mean and standard deviation (S.D). The qualitative data were presented in forms of narrative descriptions. The results positively answered the research questions by showing that the target learners who participated in the study in English Phonetics Course were able to pronounce word stress more accurately after learning through phonetic transcriptions. These results were significant at a level of 0.01. In additional, their abilities in word stress pronunciation reflected their positive attitudes through using a phonetic transcription.
\end{abstract}

Keywords: word stress, English pronunciation, a phonetics transcription

\section{Introduction}

Briefly, English is the language of globalization because there are 400 million people who use it as their first language. Moreover, some experts predicted that by 2050, half the world will be more proficient in English. Certainly, English is the worldwide language in technology and communication. (Millward and Hayes, 2012) Undoubtedly, pronunciation is an essential part for foreign language learners since it honestly affects learners' communicative competence in English. EFL learners should be directed more attention to the basic skill of pronunciation. They should be recognized and encouraged by their teachers to acquire it for the effective language accuracy and pronunciation because communication is one of the most important skills in English Language. (Celce-Murcia et al., 2000; Hahn, 2004).

Pronunciation is a fundamental skill which students need to primarily acquire because it affects comprehension and effective communication. Without it, communication breakdown can easily happen. Fraser (2000) found that English as a foreign language learners have a lot of difficulties with pronunciation. The role of English pronunciation in Thailand is quite important as it is in many is used as the means to communicate, negotiate and execute businesses by participants where one partner or none of the partners can be a native speaker of English. This could be the reason why improving the learners' pronunciation, the emphasis on teaching correct pronunciation, for example, recognizing errors in pronunciation and correcting them is necessary.

Research studies on English pronunciation are usually distributed in English as foreign language courses. However, this kind of research with Thai learners in a program called English for International Communication (EIC) under the degree of Bachelor of Arts in Rajamangala University of Technology Isan is disregarded. Specifically, the pronunciation created by learners in EIC program who are expected to be highly qualified graduates into professional executives or officers that are required to reach international standards. To serve the university's mission in an academic and professional success, pronunciation competence should be explored to produce skilled graduates dedicated to language and cultural awareness, and to train students who are wellprepared to move towards the international professional standards. 


\section{Objectives}

- To improve learners' pronunciation focusing on word stress through the use of phonetic transcriptions.

- To investigate the learners' attitudes towards practicing word stress pronunciation through the use of phonetic transcriptions.

\section{Literature Reviews}

\section{The Importance of Phonetic Transcriptions}

Stanton (2002) suggested that a language teacher should know the phonemic symbols and there are many reasons to support that it is best to prepare the learners to understand the importance of phonetics transcription as follows.

- Phonetics transcription is the graphic representation of speech sounds. The most common form of phonetic transcription uses a phonetic alphabet, such as the International Phonetic Alphabet. There are many reasons why the learners should be required to learn and recognize the phonetics transcription used in English.

- Phonetic Transcriptions can help learners to use dictionaries successfully because the second part of information in English dictionaries for language learners is the word in phonetics transcription. As a result, recognizing phonetics transcription assists learners to get the greatest report for pronouncing.

- $\quad$ To become the 21 st century skilled and autonomous learners who can find out the pronunciation of a word by themselves without asking the teacher. Moreover, they can record the correct pronunciation of a word that they receive. If they cannot use phonetics transcription for this, they will use the sound values of letters in their own language and this will keep pronunciation errors.

- Phonetic transcriptions are visual utilities for learners to see the pronunciation differences or similarities between two or more words. For example, they can see the words which are homonyms because the phonetic transcriptions are the same. They can enhance their senses of touch such as eyes and ears because the most frequencies of using their senses can help promoting their learning.

- Phonetics transcription organized in a chart which is a part of learning resources. Learners have a dictionary for vocabulary, a grammar book for grammar, so the phonetics transcription can be used as reference materials for pronunciation owing to its simple key words that show the sound of each symbol.

Moreover, these advances will be benefit to learners to get ready becoming succeed effectively with information, communication and collaboration skills in the 21 st century life.

\section{The Features of Phonetics Transcription of English Consonants and Vowels}

One of the best-known systems, the International Phonetic Alphabet (IPA), has been developing since 1888. After putting efforts to devise a universal system for transcribing the sounds of speech since the sixteenth century. This method transcription was introduced to represent each sound of human speech with a single symbol. These symbols are enclosed in brackets [ ] to signify that the transcription is phonetic and does not represent the spelling system of a particular language. 
TABLE 1: Transcript Consonants and Vowels

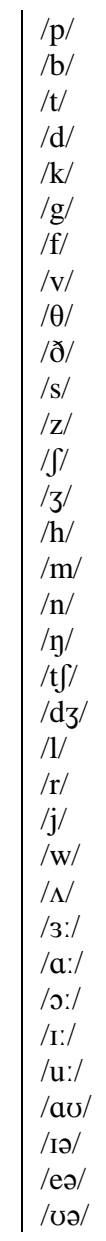

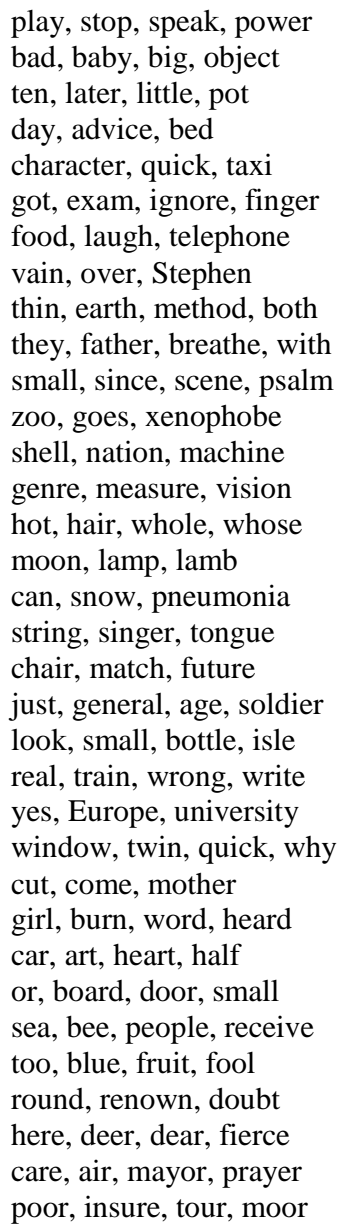

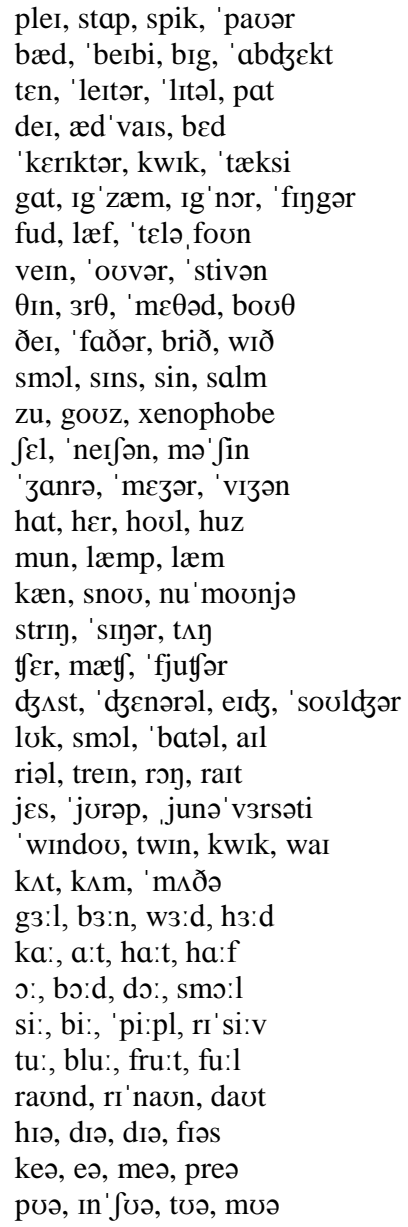

Kelly (2011) claimed that people use lips, tongue, teeth, hard to soft palettes, and alveolar ridge to pronounce English. The articulation happens when the air stream is interrupted, shaped, restricted, and diverted. The nasal cavity is used to present a few certain sounds, and the movement of the lower jaws is also required. Since this study aims at word stress development so segmental features are clarified as follows;

Ladefoged (2006) presented that the main feathers of pronunciation can divide into segmental and suprasegmental. The first category can be defined as the smallest English unit in the language, a phoneme, which is able to exchange into different meaning. Segmental is determined into two different directions of consonants and vowel sounds.

The consonant sounds are articulated with the barrier of the airflow. They may be voiced when there is a vibration at the level of the vocal cords in the larynx to produce them the examples are /b//d/ /z/ /v/. While voiceless sounds like /p/ /t/ /s/ /f/ are produced without vibration. In fact, consonants are categorized into two main aspects of place of articulation such as bilabial as $/ \mathrm{b} /$, labiodental as $/ \mathrm{f} /$, dental as $/ \theta /$, alveolar as $/ \mathrm{t} /$, palatoalveolar as $/ \mathrm{J} /$, palatal as $/ \mathrm{j} /$, velar as $/ \mathrm{k} /$ and glottal as $/ \mathrm{h} /$ and manner of articulation such as plosive as $/ \mathrm{p} /$, fricative as /s/, affricate as /dz/, nasal as / $\mathrm{y} /$, lateral as $/ 1 /$ and approximant as $/ \mathrm{w} /$ 
TABLE 2: English Consonants Classified According to Voicing, Manner, and Place of Articulations

\begin{tabular}{|c|c|c|c|c|c|c|c|}
\hline No & symbol & word & Voicing & \multicolumn{2}{|c|}{ Manner } & \multicolumn{2}{|c|}{ Place } \\
\hline 1 & $/ \mathrm{p} /$ & pot & voiceless & plosive & $\begin{array}{l}\text { IOWA } \\
\text { University }\end{array}$ & bilabial & $\begin{array}{l}\text { IOWA } \\
\text { University }\end{array}$ \\
\hline 2 & $/ \mathrm{b} /$ & bet & voiced & plosive & & bilabial & \\
\hline 3 & $/ \mathrm{t} /$ & $\operatorname{dog}$ & voiceless & plosive & & alveolar & lingua-alveolar \\
\hline 4 & $/ \mathrm{d} /$ & top & voiced & plosive & & alveolar & lingua-alveolar \\
\hline 5 & $/ \mathrm{k} /$ & kit & voiceless & plosive & & velar & lingua-velar \\
\hline 6 & /g/ & got & voiced & plosive & & velar & lingua-velar \\
\hline 7 & /f/ & fog & voiceless & fricative & & labio-dental & \\
\hline 8 & /v/ & vat & voiced & fricative & & labio-dental & \\
\hline 9 & $/ \theta /$ & thick & voiceless & fricative & & dental & lingua-dental \\
\hline 10 & /ð/ & that & voiced & fricative & & dental & lingua-dental \\
\hline 11 & $/ \mathrm{s} /$ & sat & voiceless & fricative & & alveolar & lingua-alveolar \\
\hline 12 & $|z|$ & zoo & voiced & fricative & & alveolar & lingua-alveolar \\
\hline 13 & $\mid \mathrm{g} /$ & shut & voiceless & fricative & & post-alveolar & lingua-palatal \\
\hline 14 & $\mid 3 /$ & measure & voiced & fricative & & post-alveolar & lingua-palatal \\
\hline 15 & $/ \mathrm{h} /$ & help & voiceless & fricative & & glottal & \\
\hline 16 & $\mid \mathrm{t} /$ & church & voiceless & affricate & & post-alveolar & lingua-alveolar \\
\hline 17 & $/ d z /$ & jump & voiced & affricate & & post-alveolar & lingua-alveolar \\
\hline 18 & $/ \mathrm{m} /$ & mom & voiced & nasal & & bilabial & \\
\hline 19 & $/ \mathrm{n} /$ & nod & voiced & nasal & & alveolar & lingua-alveolar \\
\hline 20 & $/ \mathrm{y} /$ & thing & voiced & nasal & & velar & lingua-velar \\
\hline 21 & $/ 1 /$ & lot & voiced & approx. & liquid & alveolar & lingua-alveolar \\
\hline 22 & $/ \mathrm{r} /$ & rat & voiced & approx. & liquid & post-alveolar & lingua-palatal \\
\hline 23 & $/ \mathrm{w} /$ & won & voiced & approx. & glide & bilabial & \\
\hline 24 & /j/ & you & voiced & approx. & glide & palatal & lingua-palatal \\
\hline
\end{tabular}

Vowels can be classified in a large number of sounds or phonemes and they are precisely of three kinds, firstly, single vowels which are divided into short and long vowels, e.g., pen /pen/, girl/g3:1/, secondly are diphthongs which combined two vowel sounds, e.g., right /raIt/, boy /bJI/ and finally, triphthongs which three vowel sounds are joined e.g., fire /faIə/, lower /ləひə/.

Furthermore, to pronounce a word which has more than two syllables, the isolated word is labeled as a word stress. To support this, Collin and Mees (2013) stated that in a more than one syllable English word or polysyllable, it is said in strongly stressed syllable which will stand out from the rest. This can be indicated by a stress mark /'/ place before the syllable concerned, e.g., 'yesterday /'jestər, deI/, to'morrow / to' ma, rou / to'day $/$ ta'deI /.

\section{Pronunciation Problems of Thai Learners}

Effective pronunciation can be reflected through two main concepts of pronunciation; improvable intelligibility and favorable impression (Poedjosoedarmo, 2003). To pronounce English words correctly and 
clearly is essential for effective communication because mispronouncing can lead the listeners misunderstand in what the speaker really intends to convey. Nevertheless, a large number of Thai learners who study English as a foreign language are encounter problems of English pronunciation, which result from several factors.

- $\quad$ Phonetic Differences

One important factor in pronunciation problems of Thai learners is the phonetic differences between English and their mother tongue. The studies of Chruatrachue (1960) and Sayankena (2008) have pointed out that some problematic sounds such as /v/, /z/, /dz/, / $\mathrm{g} /$ and /z/ do not have in the Thai language, so many Thai learners tend to use the most similar sounds to substitute them.

- Consonants, Vowels and Intonations

Similarly, the study of Wei, Youfu, Zhou, Yalun (2002) found specific characteristics of English pronunciations by pronouncing some of the final consonants of English words as un-aspirated and unvoiced like being pronounced in a Thai way. They claimed that the Romanization and intonations of the Thai language are applied into English pronunciations. Also, some Thais are sometimes shy to speak in a native English speaker's way. The study strongly mentions that teachers should provide pronunciation training courses to language learners for effective communication.

- Interferences of the Mother Tongue

Theories about second language phonological acquisition have been proposed in order to explain how and why L1 or mother tongue influence has a heavy impact on L2 learning. Zhang (2009) indicated that the more dissimilar of sound systems in a language, more trouble the learners will face. Furthermore, Lado (1961) emphasized that L2 students usually transfer their L1 system into the process of producing a target language. However, it does not mean that acquisition of the new language pronunciation is impossible. On the contrary, the more similarities the sound systems of both of the languages have, the more simplicity the learners' learning will gain.

Focusing on the specific problems on English pronunciation, Poedjosoedarmo (2003) stated that learners of English in native English situation are believed to be able to acquire the language successfully from everyday situations outside the classroom. On the other hand, most of the EFL students in countries whose first language are not English may never develop their language ability to acquire an appropriate pronunciation in such situations.

To increase learners' responsibility for their own learning, teachers need to find the right way to help them to be able to maintain effective English pronunciation. English phonetics transcription is specifically implemented in this research study to succeed this goal.

\section{Previous Related Studies}

The study of Khamkhien (2010) examined Thai learners' knowledge regarding word stress tasks and concluded the possible factors affecting Thai learners' pronunciation competency. The data were obtained from 90 personal information profiles of Thai learners, and 40 selected words to identify pronunciation competence. The research finding revealed that Thai learners' knowledge in word stress is limited. The learners' test scores also showed that the most important factor affecting the pronunciation competence was gender differences while faculty and years of studying English were not. Furthermore, the researcher highly recommend that academic suggestions can help develop teaching and learning general English pronunciation, and the significance of teaching word stress should be specifically concentrated.

\section{Research methodology}

\section{Population and sample}

The sample for this research consisted of forty-five participants with English for International Communication major selected through a purposive sampling method. The data of this study were collected from EFL learners at Rajamangala University of Technology Isan (RMUTI) as a part of an English Phonetics course in the first semester of the academic year 2016. This group of participants were chosen because it is a mixedability group which represents the population as a whole. They are the first year students so they need to be prepared for using English effectively both for their present study and future career. 


\section{Research instruments}

- Pre and Post Pronunciation Test

In order to see how the students were able to improve in learning intelligible pronunciation, pre and post tests were used to test English pronunciation focusing on word stress. The intelligible pronunciation tests were applied before and after studying of phonetic transcription. While the pretest taken at the beginning of course was used to identify their pronunciation errors by reading aloud, the posttest taken at the end of the course was used to reflect the progress of the improvement of the learners. The pronunciation test contained 30 words taken from the initial study from relevant group of learners. The stress part was divided in primary stress, secondary stress, tertiary stress, and weak stress. All thirty words were written with the phonetic transcription under each word. Words in the test were combined by group of foreign teachers in RMUTI.

- Questionnaire

The questionnaire was designed to determine the learners' attitude towards learning word stress pronunciation through phonetic transcriptions. The details from the learners was considered and interpreted in order to identify the questions needed to ask. Then the questionnaire was written by asking about learning process, contents and activities. The questionnaire was divided into two parts in the first part, 10 items were the checklist types with 5 rating scales according to Likert. The improvement of word stress pronunciation had 4 items, and usefulness of phonetic transcription had 6 items. In the second part, there were open ended type questions for learners to express their comments, problems and suggestion. This questionnaire was done after they finished the post pronunciation test.

\section{Data collection}

Over the first semester in academic year 2016, EFL bachelor degree learners were in a part of this study. The research started with the pronunciation pretest to identify the learners' problems in English pronunciation. The thirty word stresses in pronunciation test were designed based on their problems in relation to specific pronunciation features. The material was adjusted to suit this purpose specifically related to the learners' field of study. Also, the questionnaire was purposely designed to obtain the participants' opinion toward phonetic transcriptions to measure the progression of learners. Therefore, this study is both quantitative and qualitative classroom based-research. At this study implemented phonetic transcription to enhance learners' pronunciation, the words of phonetic transcription are concerned with learners' daily lives.

TABLE 3: Summary of Data Collection and Data Analysis

\begin{tabular}{|l|l|l}
\multicolumn{1}{|c|}{ Research Questions } & Data sources & Data analysis \\
\hline $\begin{array}{l}\text { - Can phonetic transcriptions } \\
\text { improve EFL learners' word } \\
\text { stress }\end{array}$ & $\begin{array}{l}\text { - Pre and post pronunciation } \\
\text { test }\end{array}$ & t-Test, Mean, S.D, \\
$\begin{array}{l}\text { - How the phonetic } \\
\text { transcriptions affect learners } \\
\begin{array}{l}\text { attitude in word stress } \\
\text { pronunciation }\end{array}\end{array}$ & - Questionnaire & $\begin{array}{l}\text { Mean, S.D, } \\
\text { content analysis } \\
\text { Summary and narration }\end{array}$
\end{tabular}




\section{Results}

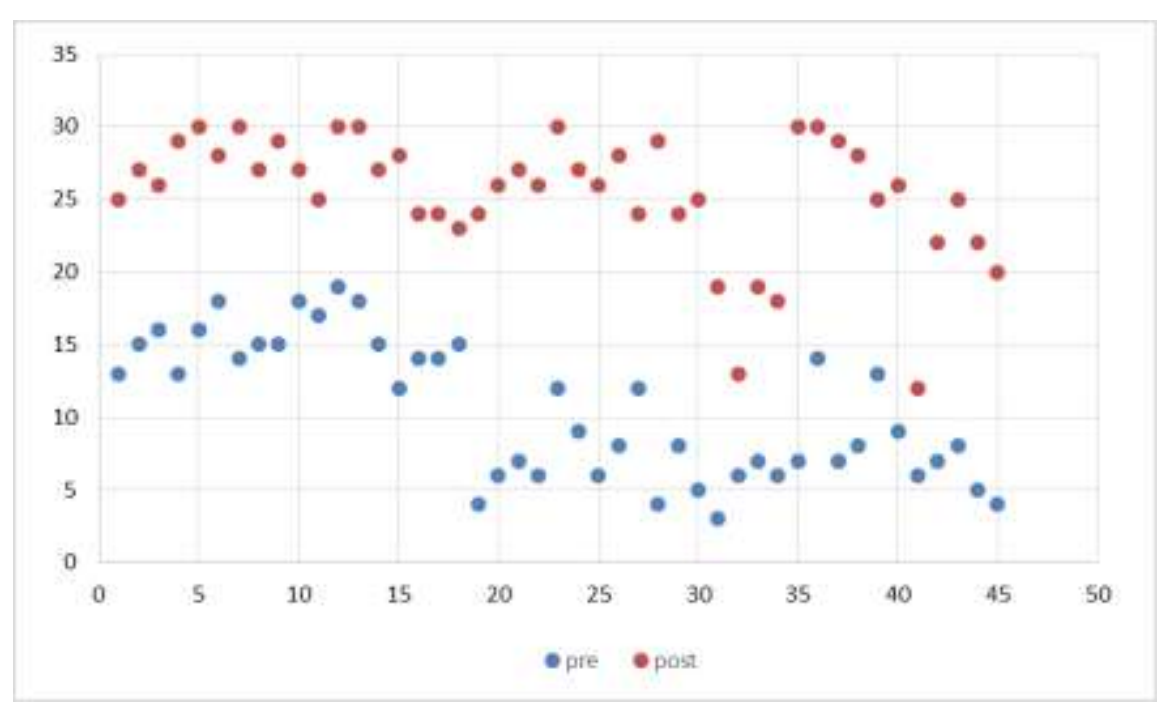

Fig. 1: The Comparisons of the Pre/Post Tests Results for Word Stress

TABLE 4: Attitudes towards Practicing Word Stress Pronunciation through the Use of Phonetic Transcriptions

\begin{tabular}{|c|c|c|c|}
\hline \multirow[t]{2}{*}{ No. } & \multirow[t]{2}{*}{ Items } & \multicolumn{2}{|c|}{ Levels of Attitude } \\
\hline & & $(\mathrm{X})$ & S.D. \\
\hline \multicolumn{4}{|c|}{ How much is your word stress pronunciation improved by phonetic transcription? } \\
\hline $\begin{array}{l}1 \\
2 \\
3 \\
4\end{array}$ & $\begin{array}{l}\text { I pronounce English word stress better and more fluently. } \\
\text { I can pronounce English word stress for communication. } \\
\text { My ability in word stress pronunciation was improved. } \\
\text { My understanding in word stress pronunciation was } \\
\text { increased. }\end{array}$ & $\begin{array}{l}3.62 \\
3.62 \\
3.92 \\
3.67\end{array}$ & $\begin{array}{l}0.80 \\
0.89 \\
0.76 \\
0.82\end{array}$ \\
\hline \multicolumn{4}{|c|}{ How useful is phonetic transcription to the learners? } \\
\hline 5 & I can understand the lesson more. & 3.72 & 0.87 \\
\hline 6 & $\begin{array}{l}\text { I enjoy practicing word stress pronunciation by using } \\
\text { phonetic transcription? }\end{array}$ & 4.55 & 0.63 \\
\hline 7 & $\begin{array}{l}\text { Phonetic transcription is appropriate in the pronunciation } \\
\text { course. }\end{array}$ & 4.17 & 0.71 \\
\hline 8 & I can use what I have studied in my daily life. & 3.75 & 0.77 \\
\hline 9 & I have more confident to pronounce English word stress. & 3.95 & 0.50 \\
\hline 10 & $\begin{array}{l}\text { This activity makes me want to practice English } \\
\text { pronunciation continuously. }\end{array}$ & 4.30 & 0.75 \\
\hline \multicolumn{2}{|r|}{ Total } & 3.92 & 0.75 \\
\hline
\end{tabular}

The result in table 4 showed that the participants have good attitudes towards phonetic transcription. They felt their competence in word stress pronunciation was improved because they could pronounce English word in many different kinds of stress patterns. Furthermore, the participants believed that phonetic transcription is useful for them. They had greater confidence to pronounce English word stress and they were willing to practice the activities provided. the analysis of the data revealed that the mean score (x) of all items was 3.92 and the standard deviation was 0.75 it can be concluded that phonetic transcription provided learners better word stress pronunciation and it is also useful for them.

Additionally, the answer from open ended questions concluded as the comments, and the suggestions about practicing word stress pronunciation through phonetic transcription is as follows:

\section{Comments}

1. The participants have more confident to pronounce English word stress.

2. The learners' pronunciation competence focusing on word stress was improved.

3. The pronunciation competence can be adapted to be used in their daily lives. 


\section{Problems}

1. Some participants were nervous and afraid to pronounce English word stress.

2. The time provided was not enough.

3. Some participants got confused with the Phonetic symbols.

\section{Suggestions}

1. The participants required more time to memorize the different Phonetic symbols.

2. The native speaker should be invited to be an expert in pronouncing English word stress.

3. Teacher should teach sentences or intonation, which are really used in participants' daily lives.

\section{Acknowledgements}

I would like to express my sincerest gratitude and deep appreciation to all the persons who assisted in the completion of this research. I am greatly indebted to Miss Anchalee Veerachaisantikul, my research colleague who encouraged and provided constant suggestions to make this study possible.

My deepest gratitude to Rajamangala University of Technology Isan for supporting my research with the knowledge sources and some of working time, I also wish to thank the first year bachelor's degree learners majoring in English for International Communication at Rajamanagala University of Technology Isan, Nakhon Ratchasima for their cooperation in participating in this study.

\section{References}

[1] Celce-Murcia, M., Brinton, D., \& Goodwin, J. Teaching Pronunciation: A Reference for Teachers of English to Speakers of Other Languages. Cambridge: Cambridge University Press. (2000).

[2] Chruatrachue, F. Thai and English: A Comparative Study of Phonology for Pedagogical Applications. Thesis Ph.D. Indiana University. (1960).

[3] Collin, B.S. and Mees, I. Practical Phonetics and Phonology: a resource book for students, Beverly Collins\&Inger, Routledge., NewYork. (2013).

[4] Fraser, H. Coordinating Improvement in Pronunciation Teaching for Adult Learners of English as a Second Language. Canberra: Department of Education, Training and Youth Affairs. (2000).

[5] Hahn, L. Primary stress and intelligibility: Research to motivate the teaching of suprasegmental. TESOL Quarterly, 38, p. 201-223. (2004). https://doi.org/10.2307/3588378

[6] Katamba, F., William D., Dobrovolsky, M. Contemporary linguistics: an introduction Longman, London; New York [Online]. (1997). Available: http://catalogue.pearsoned.co.uk/ assets/hip/gb/uploads/Katamba9781405899307_Ch2 .pdf

[7] Kelly, G. How to Teach Pronunciation. Harlow, Essex: Pearson Longman. (2011).

[8] Khamkhien, A. (2010). Thai Learners' English Pronunciation Competence Lesson Learned from Word Stress Assignment. Journal of Language Teaching and Research. [Online]. Available: http://www.academypublication.com/issues/past/jltr/vol01/06/01.pdf.

[9] Ladefoged, P. A Course in Phonetics (5th ed). Boston: Thomson Wadsworth. (2006).

[10] Phonetics the Sound of American English [Online]. Available: http://soundsofspeech.uiowa.edu/english/english.html

[11] Poedjosoedarmo, G. Teaching Pronunciation Why, What, when, and How. RELC:, Portfolio Series (9), Singapore, SEAMEO Regional Language Center. (2003).

[12] Stanton, A. Teaching pronunciation with phonemic symbols. [On-line].(2002). Available: https://www.teachingenglish.org.uk /article/teaching-pronunciation-phonemic-symbols

[13] Wei, Y., \& Zhou, Y. (8th, April 6, 2002) Insights into English Pronunciation Problems of Thai Students. In The annual meeting of quadruple helix (2002).

[14] Zhang, Y. Reading to speak: Integrating oral communication skills. English (2009). 